\title{
「テラバイト時代を拓く近未来光メモリ技術」解説小特集号によせて
}

\author{
沖野芳弘 \\ 関西大学先端科学推進機構HRC（†561-8680 吹田市山手町3-3-35）
}

\section{Topical Papers on Tera Byte World by Optical Memory Technology in Near Future}

\author{
Yoshihiro OKINO \\ High-technology Research Center, Organization for Research and Development of Innovative Science and technology, Kansai University \\ 3-3-35, Yamate-cho, Suita, Osaka 561-8680
}

(Received December 1, 2003)

昨今，「DVD」関連製品が大きなビジネスとなり景気を 牽引する商品として認識され始めている. その余勢で次 世代のDVDと言われる青色レーザーを搭載したエンジン を持つシステムの研究・開発が急ピッチであり, ようや くその方向が固まりつつあると見受けられる。青色レー ザーそのものを始めまだ大量生産を開始出来るところま でには至っていないが，既に先行商品が発売される様な 状況である。

オランダPhilips社が1972年に開発発表を行ったレーザー ディスク $(\mathrm{LD}) ， 1982$ 年10月に全世界一斉に商品発売が開 始されたCD (Compact Disc)，1996年に商品化が始まった DVD，更には上述の次世代DVDは過去30有余年に渡る技 術の流れは, 多難で多様かつ時代の流れに振られて来た が，一貫している筋は，レーザービームを大きな開口数 (Numerical Aperture :NA) を持つ対物レンズで記録平面上 に光ピックアップヘッドをキーデバイスとする方式であ る.すなわち高密度化に当たってはレーザー光の波長を 短くする事，レンズのNAを大きくする事を中心課題とし て, 信号処理技術やこれらに付随して派生する課題を解 決する事が技術の中心命題であった.

しかし, 次世代DVDで採用される青色レーザー(波長 $405 \mathrm{~nm})$ と $N A=0.85$ のレンズの次は, 実用レベルで「後が無 い」とも云われる. 光メモリはここでいったん止まってし まうのであろうか? そんな危惧も当然生じてくる. 次 に飛躍する技術において，また利用形態において光メモ リのブレークポイントを何処に求めれば良いのか, それ が近未来に期待される光メモリの重要な研究課題であ る.

最初に光メモリの現在までのメインストリームを簡単 に述べたが，ここまで到達するためには現場の研究者・ 技術者にとっては紆余曲折の長い歴史を経験してきた. 結果として述べるとこの様なシンプルな話になるが, 社
会状況から来る時代の要請と挑戦する技術の極限との兼 ね合いでその流れが作られてきた。未来においてもそれ は変わらない，ギガからテラへの高密度化や高速化の技 術は重要なポイントになるが，その実用上の要請により 高信頼化，高機能化，などの別の要素が入るかも知れな い. また技術の極限の追求から従来考え得なかった可能 性が見いだせるかも知れないと云う夢の部分の展開もあ る.

2003 年度のこの分野での大きな国際会議として ODS2003(5月)およびISOM2003，Nara(11月)があった。こ のシンポジウムで発表され議論された幾つかの近未来型 の光メモリ技術は, 現在という時代の断面の中でその動 向を教えてくれるものである。この中で拾ってみると， 第一には，二次元的な面の中だけで考えていた，情報を 担持する記録媒体を三次元に拡げて考える流れである. この中には既にDVDで利用されている多層構造媒体や, 古くて新しいホログラム記録の様な技術が含まれる. 次 には近接場光学を利用するもので, これには液浸レンズ (LIL) ・ Solid Immersion Lens (SIL)の延長として開口数を 従来考えられなかった大きな值にする技術として捉える 事もできるが，その原理や態様で大きく異なるものであ る。この中には媒体の中に仕組みを作って近接場光の出 射開口を作るSuper-RENSと呼ばれる方式なども含まれ る.

これら以外にも多值記録(再生)など様々な技術が存在し たし，またこれからも新しい提案が出てくると思われ る。また，光だけではなく，例えば磁気，化学，エレク トロニクスなど他の技術との融合によって作られる期待 もある。これらの技術が新しいブレークポイントを作っ て, 新たな活用局面や技術の展開がなされるものと期待 される. 本特集がその点において何らかのトリガーと なって研究・開発が促進されれば幸いな事である。 